Jurnal Keperawatan Silampari

Volume 3, Nomor 2, Juni 2020

e-ISSN: 2581-1975

p-ISSN: 2597-7482

DOI: https://doi.org/10.31539/jks.v3i2.1200

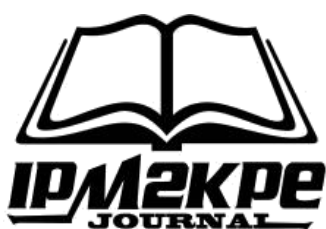

\title{
ACUPRESSURE DAN SENAM KAKI TERHADAP TINGKAT PERIPHERAL ARTERIAL DISEASE PADA KLIEN DM TIPE 2
}

\author{
Linda Widiastuti \\ Sekolah Tinggi Ilmu Kesehatan Hang Tuah Tanjungpinang \\ lindawidiastuti078@gmail.com
}

\begin{abstract}
ABSTRAK
Penelitian ini bertujuan mengetahui pengaruh intervensi acupressure, senam kaki dan gabungan acupressure dengan senam kaki terhadap tingkat PAD pada klien DM tipe 2. Desain penelitian kuantitatif kuasi eksperimen pre-post test design. Hasil penelitian didapatkan ada hubungan yang signifikan usia $(p=0,000)$, riwayat merokok $(p=0,000)$, dan lama menderita DM ( $\mathrm{p}=0,028)$ dengan tingkat PAD. Hasil uji beda berpasangan didapatkan ada perbedaan yang signifikan tingkat PAD sebelum dan sesudah intervensi pada kelompok acupressure $(\mathrm{p}=0,000)$, senam kaki $(\mathrm{p}=0,000)$ dan gabungan acupressure dengan senam kaki $(\mathrm{p}=0,000)$. Hasil uji regresi logistik ordinal menunjukkan bahwa gabungan acupressure dengan senam kaki memberikan pengaruh paling kuat terhadap tingkat PAD $(\mathrm{p}=0,000)$ dengan kontribusi sebesar $36,4 \%$, acupressure $(\mathrm{p}=0,005)$ dengan kontribusi sebesar $30,2 \%$, dan senam kaki $(\mathrm{p}=0,033)$ dengan kontribusi sebesar 20,6\%. Simpulan, acupressure dan senam kaki berpengaruh terhadap tingkat PAD klien DM tipe 2.
\end{abstract}

Kata Kunci : Acupressure, DM tipe 2, Peripheral Arterial Disease, Senam Kaki

\section{ABSTRACT}

This study aims to determine the effect of acupressure intervention, foot gymnastics, and acupressure combination with foot gymnastics on the level of PAD in type 2 DM clients. The results showed that there was a significant relationship between age $(p=0,000)$, smoking history $(p=0,000)$, and duration of DM $(p=0.028)$ with the level of PAD. Paired difference test results found that there were significant differences in the level of $P A D$ before and after the intervention in the acupressure group $(p=0,000)$, foot gymnastics $(p=0,000)$, and the combination of acupressure with foot gymnastics ( $p=$ $0,000)$. The results of the ordinal logistic regression test showed that the combination of acupressure with foot exercises gave the strongest influence on the level of PAD ( $p=$ $0,000)$ with a contribution of $36.4 \%$, acupressure $(p=0.005)$ with a contribution of $30.2 \%$, and foot exercises ( $p=0.033)$ with a contribution of $20.6 \%$. Conclusions, acupressure, and foot exercises affect the level of PAD of type 2 DM clients.

Keywords: Acupressure, DM type 2, Peripheral Arterial Disease, Foot Gymnastics

\section{PENDAHULUAN}

Diabetes Melitus (DM) merupakan kelompok penyakit metabolik dengan karakteristik hiperglikemia yang terjadi karena kelainan sekresi insulin, kerja insulin, atau keduanya. Klasifikasi DM secara umum terdiri atas DM tipe 1 atau Insulin 
Dependent Diabetes Melitus (IDDM) dan DM tipe 2 atau Non Insulin Dependent Diabetes Melitus (NIDDM). DM tipe 2 terjadi karena sel $\beta$ pankreas menghasilkan insulin dalam jumlah sedikit atau mengalami resistensi insulin. Jumlah penderita DM tipe 1 sebanyak 5-10\% dan DM tipe 2 sebanyak 90-95\% dari penderita DM di seluruh dunia (ADA, 2020).

DM sebagai permasalahan global terus meningkat prevalensinya dari tahun ke tahun baik di dunia maupun di Indonesia. Berdasarkan data International Diabetes Federation (IDF) prevalensi DM global pada tahun 2019 diperkirakan 9,3\% (463 juta orang), naik menjadi 10,2\% (578 juta) pada tahun 2030 dan 10,9\% (700 juta) pada tahun 2045 (IDF, 2019). Pada tahun 2015, Indonesia menempati peringkat 7 sebagai negara dengan penyandang DM terbanyak di dunia, dan diperkirakan akan naik peringkat 6 pada tahun 2040 (Perkeni, 2019).

Laporan Riskesdas tahun 2018 menyebutkan terjadi peningkatan prevalensi pada penderita DM 2,0\% pada tahun 2013 menjadi 3,4\% pada tahun 2018, dengan jumlah penderita DM di Kepulauan Riau sebesar 1,68\% (8.060 orang) dari seluruh jumlah penderita DM di Indonesia (Riskesdas, 2018).

Di kota Tanjungpinang, jumlah penderita DM berdasarkan data laporan Rikesdas Provinsi (2018) Kota Tanjungpinang naik dari 560 orang tahun 2013 menjadi 822 orang (peningkatan 31,8\%) tahun 2018 (Kemenkes RI, 2018). Data rekam medis penderita DM tahun 2018, kunjungan rawat jalan di RSAL dan RSUD kota Tanjungpinang sebesar 452 orang (peningkatan 23\%) dari tahun sebelumnya.

DM merupakan penyakit menahun yang akan disandang seumur hidup. Dan keadaan ini akan berdampak terhadap komplikasi dari DM salah satunya adalah Peripheral Arterial Disease (PAD) yaitu terbentuknya aterosklerosis akibat penebalan membran basal pembuluh darah besar dan kecil pada aliran darah arteri perifer di ektermitas bawah. Faktor resiko PAD pada penderita DM tipe 2 meningkat seiring dengan bertambahnya usia, jenis kelamin, lama menderita DM, riwayat hipertensi, aktifitas fisik yang rendah dan riwayat merokok serta hiperkolesterolnemia (Kanokphichayakrai et al., 2018).

Prevalensi PAD meningkat pada usia rata-rata lebih dari 63 tahun dengan riwayat DM atau merokok dan usia kurang dari 40 tahun dengan DM yang disertai dengan salah satu faktor resiko tambahan seperti merokok, hipertensi atau kadar kolesterol yang tinggi (Chen et al., 2018). Selanjutnya Chen et al, tahun 2018 menjelaskan bahwa faktor resiko PAD pada penderita DM (887 pasien (80,9\%) dengan PAD dari 1096 pasien DM tipe 2) meningkat pada usia rata-rata $\geq 63$ tahun, dengan lama menderita $\mathrm{DM} \geq 9$ tahun, riwayat hipertensi sebesar $67,5 \%$, aktifitas fisik yang rendah sebesar $23 \%$, pada perokok sebesar 32,4\% dengan masing-masing $p$ value $<0,001$ dibandingkan dengan pasien bukan PAD (Chen et al., 2018). Menurut ADA (2018) mencatat penderita DM di Inggris, $40 \%$ pasien rawat inap dan $73 \%$ pasien gawat darurat dengan DM kehilangan anggota tubuh (amputasi) akibat PAD.

PAD merupakan faktor resiko terjadinya ulkus, gangren, dan penyembuhan luka yang lambat akibat sirkulasi darah yang tidak lancar pada ekstermitas yang dapat menyebabkan amputasi ektermitas bawah pada penderita DM. Salah satu tanda gejala PAD, adanya mati rasa pada telapak kaki yang disebabkan gangguan sistem syaraf perifer yang sangat erat hubungannya dengan dampak hiperglikemik kronik dan faktor neurovaskuler yang menyebabkan kerusakan pembuluh darah yang membawa oksigen dan nutrisi ke syaraf. Disfungsi syaraf perifer pada PAD menyebabkan terjadinya penurunan sensasi kaki (Muhammad, 2018). Resiko amputasi pada PAD meningkat dua 
hingga empat kali lipat dengan adanya penambahan usia dan lama penyakit pada penderita DM tipe 2. Di negara-negara Barat, jenis kelamin pria mempunyai faktor resiko terjadinya ulkus gangren 1,6 kali lipat dari pada perempuan (ADA, 2018). Resiko amputasi pada pasien DM 10 - 30 kali dibandingkan dengan penderita non DM (Muhammad, 2018).

Deteksi PAD dapat dinilai dengan pemeriksaan hasil akle brachial index $(\mathrm{ABI}) \leq$ 0,90 Chen et al., (2018) Uji ABI merupakan suatu pemeriksaan tes diagnostik murah sederhana untuk mendeteksi PAD. Pengukuran ABI yaitu perbandingan antara tekanan darah sistolik ankle dan sistolik brachial. Akurasi uji ABI untuk deteksi PAD telah dibuktikan oleh Kanokphichayakrai et al., (2018) di Hospital Phitsanulok Thailand terhadap 187 penderita DM tipe 2 untuk mengkaji sensitivitas dan spesifisitas dari ABI $\leq 0,90$ untuk mendiagnosis PAD. Didapatkan tingkat spesifisitas tinggi $(84,3-98,8 \%)$ dan akurasi (72,1-89,2\%), namun tingkat sensitivitas bervariasi (15-79\%) dalam mendeteksi 50\% PAD.

Menurut Qi et al., (2018) dan Suyanto (2017) menyatakan bahwa dengan melakukan latihan fisik dan acupressure merupakan strategi tindakan intervensi yang lebih efektif untuk mencegah dan mengobati PAD pada penderita DM. Acupressure merupakan terapi komplementer yang aman, tidak ada efek samping, bermanfaat dan dapat dilakukan sendiri dengan cara tehnik pemijatan atau tekanan menggunakan jari tangan atau alat pada titik meridian (Feng et al., 2018). Sedangkan latihan fisik atau olahraga yang direkomendasikan adalah senam kaki DM. Senam kaki diabetik merupakan kegiatan atau latihan dengan intensitas sedang yang dilakukan oleh pasien DM untuk mencegah terjadinya luka dan membantu melancarkan peredaran darah bagian kaki. Latihan intensitas sedang dapat menyebabkan pemulihan fungsi saraf perifer dengan menghambat reduktase aldosa (AR) yang mengarah ke menurunnya NADPH (Nicotinamide Adenine Dinucleotide Fosfat Hidroksida). Penurunan NADPH dapat berkontribusi dalam meningkatkan sintesis nitrat oksida (NO) yang akan menghilangkan hipoksia pada saraf. Peningkatan endotel berasal nitrat oksida (NO) juga dapat menyebabkan pemulihan fungsi saraf pada pasien DM. Tindakan senam kaki diabetik dapat meningkatkan nitrat oksida dan penghambatan produksi berlebihan protein kinase C (American Diabetes Association, 2018).

Penderita DM tipe 2 sering tidak menyadari bahwa mereka terkena PAD karena ketidaktahuan akan tanda dan gejala dari PAD. Pencegahan PAD dapat dilakukan dengan meningkatkan self care pada penderita DM. Teori self care Orem bertujuan untuk melatih kemandirian pasien dalam melakukan perawatan diri guna mempertahankan kesehatannya. Perawatan diri (Self Care) yang baik dapat membantu mencegah terjadinya komplikasi PAD. Hal ini sesuai dengan penelitian Indriani et al., (2019) terdapat hubungan antara self care dengan kejadian komplikasi PAD pada pasien DM tipe 2 dengan $p$ value $0,010(p<0,05)$.

Berdasarkan studi pendahuluan yang dilakukan di RSAL Dr. Midiyato S, RSUD Kota Tanjungpinang dan Puskesmas Batu 10 didapatkan jumlah penderita DM tipe 2 dalam tiga bulan terakhir bulan Oktober - Desember 2019 yaitu sebanyak 267 orang. Berdasarkan hasil observasi dengan 12 orang pasien DM tipe 2 di RSAL Dr Midiyato S mengalami PAD dengan nilai ABI 0,40 - 0,90 dengan kriteria PAD ringan dan sedang. Dari hasil pemeriksaan vascular dopler didapatkan 8 orang pasien dengan PAD sedang dan, 4 orang pasien PAD ringan. Selain perawat memberikan acupressure yaitu teknik penekanan pada titik tertentu (yang dikenal dengan nama acupoint) pada kaki pasien juga diberikan latihan fisik dengan cara senam kaki. 
Penelitian - penelitian sebelumnya membahas tentang DM tipe 2 secara umum. Terapi yang diberikan tehnik komplementer masih belum optimal dilakukan, penatalaksanaan pada umumnya dengan menggunakan farmakologi maupun herbal dan pengecekan gula darah. Namun penelitian ini memfokuskan pada intervensi acupressure dan senam kaki untuk mendeteksi dini PAD serta mengurangi resiko amputasi pada pasien DM tipe 2. Selain itu, penelitian ini membahas lebih spesifik PAD pada pasien DM tipe 2.

\section{METODE PENELITIAN}

Penelitian ini dilakukan menggunakan quasi eksperiment pre-post test design pada tiga kelompok perlakuan acupressure, senam kaki, dan gabungan acupressure dengan senam kaki dan satu kelompok kontrol. Sebelum diberikan intervensi dilakukan pengukuran ABI dengan menggunakan vascullar dopller. Setelah diperoleh Pre nilai ABI pada tingkat PAD, tahan selanjutnya adalah dengan memberikan acupressure pada titik Yanglingquan (GB 36); titik Zusanli (ST 36); titik Yinlingquan (SP 9); titik Sanyinjiao (SP 6); titik Jiexi (ST 41) dilakukan setiap tiga kali dalam seminggu. Prosedur senam kaki responden melakukan gerakan kaki secara bergantian (8 gerakan senam kaki) selama 15-30 menit setiap tiga kali dalam seminggu selama empat minggu. Setelah dilakukan selama empat minggu, kemudian dilakukan pengukuran nilai post dengan menggunakan vascullar doplle pengukuran ABI.

Tehnik sampling yang digunakan simple random sampling sebanyak 132 responden. Data diolah menggunakan program computer. Kaji etik dalam penelitian ini dilakukan oleh Komite Etik Penelitian Kesehatan (KEPK) Sekolah Tinggi Ilmu Kesehatan Hang Tuah Tanjungpinang.

Titik acupressure pada pasien DM untuk mencegah terjadinya PAD

Titik Yanglingquan (GB 36)

Titik Zusanli (ST 36)

Titik Jiexi (ST 41)

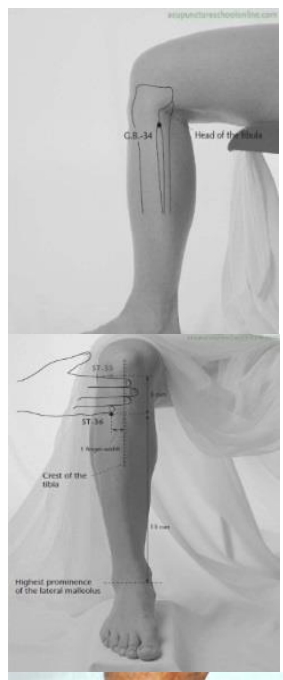

Titik Yinlingquan (SP 9)

Titik Sanyinjiao (SP 6)
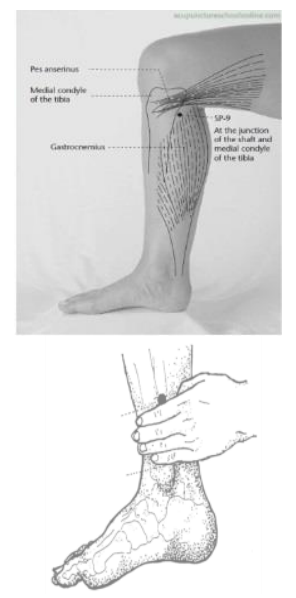
HASIL PENELITIAN

Tabel. 1

Distribusi Karakteristik Responden

\begin{tabular}{|c|c|c|c|}
\hline No & Karakteristik & $\mathrm{n}$ & $\%$ \\
\hline \multirow[t]{4}{*}{1} & Usia & & \\
\hline & 45-59 tahun & 61 & 46 \\
\hline & $60-74$ tahun & 67 & 51 \\
\hline & $>74$ tahun & 4 & 3 \\
\hline \multirow[t]{3}{*}{2} & Jenis kelamin & & \\
\hline & Laki - laki & 28 & 21 \\
\hline & Perempuan & 104 & 79 \\
\hline \multirow[t]{8}{*}{3} & Riwayat Merokok & & \\
\hline & Tidak Merokok & 106 & 80 \\
\hline & Merokok & 11 & 9 \\
\hline & 1-10batang/hari & 5 & 4 \\
\hline & 11-20batang/hari & 5 & 4 \\
\hline & 21-30batang/hari & 1 & 1 \\
\hline & $>$ 30batang/hari & 0 & 0 \\
\hline & Mantan Merokok & 15 & 11 \\
\hline \multirow[t]{8}{*}{4} & Riwayat Hipertensi & & \\
\hline & Tidak ada Riwayat Hipertensi & 53 & 40 \\
\hline & Ada Riwayat Hipertensi & 79 & 60 \\
\hline & Hipertensi & & \\
\hline & Normal & 12 & 9 \\
\hline & Pre Hipertensi & 30 & 23 \\
\hline & Hipertensi (stage I) & 59 & 44 \\
\hline & Hipertensi (stage II) & 31 & 24 \\
\hline \multirow[t]{3}{*}{5} & Lama menderita DM & & \\
\hline & $<10$ tahun & 64 & 49 \\
\hline & $>10$ tahun & 68 & 51 \\
\hline Total & & 132 & 100 \\
\hline
\end{tabular}

Berdasarkan tabel 1 diketahui karakteristik mayoritas responden: rentang usia 6074 tahun $62(51 \%)$, jenis kelamin perempuan 104 (79\%), riwayat tidak merokok 106 (80\%), riwayat hipertensi 79 (60\%), lama menderita DM lebih dari 10 tahun 68 (51\%), mengikuti kegiatan senam diabetes 94 (71\%).

Tabel. 2

Hasil Uji Hubungan Karakteristik Responden dengan Tingkat PAD

\begin{tabular}{lc}
\hline \multicolumn{1}{c}{ Karakteristik Responden } & $\begin{array}{c}\text { Tingkat PAD } \\
\text { p value }\end{array}$ \\
\hline Usia & 0,000 \\
Jenis Kelamin & 0,705 \\
Riwayat Merokok & 0,000 \\
Hipertensi Atau Riwayat Hipertensi & 0,487 \\
Lama Menderita DM & 0,028 \\
\hline
\end{tabular}

Berdasarkan tabel 2 diketahui ada hubungan yang signifikan usia, riwayat merokok, dan lama menderita DM dengan tingkat PAD dengan $\mathrm{p}$ value $<0,05$. Tidak ada hubungan yang signifikan jenis kelamin, hipertensi atau riwayat hipertensi, dan senam diabetes dengan tingkat PAD dengan $\mathrm{p}$ value $>0,05$. 
Tabel. 3

Hasil Uji Beda Berpasangan Tingkat PAD Sebelum dan Sesudah pada Kelompok Perlakuan

\begin{tabular}{|c|c|c|}
\hline No & Kelompok & $p$ value \\
\hline 1 & Acupressure & 0,000 \\
\hline 2 & Senam kaki & 0,000 \\
\hline 3 & Gabungan acupressure dengan senam kaki & 0,000 \\
\hline
\end{tabular}

Berdasarkan tabel 3 didapatkan nilai $\mathrm{p}<0,005$ pada ketiga kelompok. Ini menunjukkan bahwa secara statistik ada perbedaan tingkat PAD sebelum dan sesudah intervensi pada semua kelompok.

Tabel. 4

Hasil Uji Beda Independen

\begin{tabular}{clc}
\hline No & \multicolumn{1}{c}{ Kelompok } & p value \\
\hline 1 & Acupressure dengan senam kaki & 0,278 \\
2 & Acupressure dengan Gabungan & 0,283 \\
3 & Acupressure dengan Kontrol & 0,008 \\
4 & Senam kaki dengan Gabungan & 0,055 \\
5 & Senam kaki dengan Kontrol & 0,133 \\
6 & Gabungan dengan Kontrol & 0,001 \\
\hline
\end{tabular}

Berdasarkan tabel 4 diketahui ada perbedaan yang bermakna terhadap tingkat PAD antar kelompok intervensi acupressure dengan kelompok kontrol $(\mathrm{p}=0,008)$; antara kelompok intervensi gabungan acupressure dengan senam kaki dengan kelompok kontrol $(\mathrm{p}=0,001)$.

Tabel. 5

Uji Pseudo R-Square antar Kelompok Intervensi

\begin{tabular}{cc}
\hline Kelompok Intervensi & Cox and \\
Snell \\
\hline Acupressure & 0,302 \\
Senam kaki & 0,206 \\
Gabungan acupressure dengan senam kaki & 0,364 \\
\hline
\end{tabular}

Berdasarkan tabel 5 disimpulkan bahwa kelompok yang memberikan kontribusi paling besar terhadap variabel dependen adalah kelompok intervensi gabungan acupressure dengan senam kaki sebesar 36,4\%. Artinya gabungan acupressure dengan senam kaki secara simultan memberikan kontribusi yang paling besar terhadap tingkat PAD.

Tabel. 6

Perbandingan Besar Pengaruh Setiap Intervensi terhadap PAD

\begin{tabular}{lcc}
\hline \multicolumn{1}{c}{ Variabel Independen } & Hasil Parameters & p value \\
\hline Acupressure & Estimates & 0,005 \\
Senam Kaki & $-1,952$ & 0,033 \\
Gabungan Acupressure dengan Senam Kaki & $-0,698$ & 0,000 \\
\hline
\end{tabular}


Berdasarkan tabel 6 didapatkan nilai $\mathrm{p}<0,05$ pada semua kelompok sehingga secara statistik ada pengaruh yang signifikan pada semua kelompok intervensi terhadap tingkat PAD: intervensi gabungan acupressure dengan senam kaki adalah yang paling kuat $(\mathrm{p}=0,000)$, intervensi acupressure $(\mathrm{p}=0,005)$ dan intervensi senam kaki $(\mathrm{p}=0,033)$.

\section{PEMBAHASAN}

\section{Karakteristik Responden}

Hasil penelitian ini menunjukan bahwa dari 132 subjek penelitian, mayoritas responden berada pada rentang usia 60-74 tahun sebanyak 62 responden $(51 \%)$, hanya 4 responden $(3 \%)$ berusia $>74$ tahun dan tidak ada responden berusia $40-45$ tahun. Sebagian besar klien yang berobat jalan di poli penyakit dalam RSAL, RSUD dan Puskesmas Batu 10 yang didapatkan berdasarkan anamnesis atau rekam medis usia minimal responden 45 tahun dan usia maksimal 85 tahun dengan rata-rata usia 59,5 tahun. Terbukti pada penelitian Kanokphichayakrai et al., (2018) terhadap 31 dari 187 penderita DM tipe 2 yang memperoleh hasil penelitian bahwa PAD pada kelompok rentang usia 60,5 - 73,5 tahun dengan rata-rata usia 65 tahun. Kesimpulan dari penelitian ini bahwa bertambahnya usia dapat berpengaruh terhadap kejadian PAD dengan $\mathrm{p}$ value $=0,001(\mathrm{p}<0,05)$. Menurut IDF (2019) bahwa penderita DM mengalami peningkatan pada usia 60 - 74 tahun sebesar $20 \%$ pada tahun 2019.

Menurut ADA (2018) bahwa penderita DM tipe 2 dapat terjadi diantara usia 4564 tahun. Pada usia lebih dari 45 tahun tubuh mengalami proses penuaan yang menyebabkan berkurangnya kemampuan sel $\beta$ pankreas dalam memproduksi insulin. Pada individu yang berusia lebih tua terdapat penurunan aktifitas mitokondria di sel-sel otot sebesar 35\% yang mengakibatkan kadar lemak di otot meningkat 30\% sehingga terjadinya resistensi insulin dan gangguan sekresi insulin. Kadar glukosa darah yang meningkat dapat mengganggu sirkulasi darah karena dapat mengakibatkan penumpukan glukosa dalam pembuluh darah, sehingga pembuluh darah menjadi kaku dan menyempit (atherosklerosis).

Dilihat dari karakteristik jenis kelamin, menunjukkan mayoritas responden perempuan sebanyak 104 responden (79\%). Data ini mengindikasikan bahwa perempuan mempunyai kecenderungan lebih besar untuk menderita DM tipe 2 dibandingkan laki-laki. Terbukti pada penelitian Qi et al., (2018) terhadap 126 pasien DM tipe 2 di China. Hasil penelitian ini menunjukkan bahwa frekuensi pasien DM tipe 2 didapatkan bahwa 49 orang (76\%) merupakan perempuan. Menurut IDF (2019) bahwa DM lebih banyak diderita pada perempuan dibandingkan laki-laki pada tahun 2019. Perempuan yang berusia lebih dari 45 tahun akan mengalami ketidak seimbangan kadar hormon dalam memasuki masa menopause yang menyebabkan kadar gula darah tidak terkendali. Pada penelitian ini mayoritas responden tergolong dalam kelompok usia yang mengalami menopause.

Perempuan lebih berpeluang terkena DM karena premestrual sindrome dan pasca menopause yang mengakibatkan distribusi lemak didalam tubuh terakumulasi akibat dari gangguan hormonal estrogen. Penurunan hormon estrogen mengakibatkan vasokontriksi pada pembuluh darah, meningkatkan kadar LDL terjadi proses pembentukan fatty streak merupakan prekusor dari ateroma sampai terbentuknya arterosklerosis pada pembuluh darah arteri cabang viseral sehingga mengalami gangguan sirkulasi pembuluh darah di ektermiatas bawah yang dikenal dengan PAD (American Diabetes Association, 2018). Dari hal diatas dapat dilihat bahwa perempuan dengan DM lebih beresiko mengalami PAD dibandingkan dengan laki-laki. 
Karakteristik riwayat merokok, menunjukkan mayoritas responden tidak merokok, mayoritas terdistribusi pada kelompok acupressure sebanyak 4 yang merokok 1-10 batang perhari. Terbukti pada penelitian Akalu, Birhan, (2020) terhadap 280 pasien DM tipe 2 di Ethiopia. Hasil penelitian menunjukkan bahwa mayoritas responden tidak merokok sebanyak $220(78,67 \%)$ pada pasien DM tipe 2 dengan PAD.

Hal ini menunjukkan bahwa pasien DM tipe 2 dengan riwayat tidak merokok (perokok pasif) memiliki faktor resiko terjadi PAD tujuh kali dibandingkan dengan merokok (perokok aktif). PAD dapat terjadi disebabkan oleh efek toksik dari nikotin, karbon monoksida, dan bahan lainnya masuk ke dalam pembuluh darah. Nikotin merusak vasodilatasi pada endotelium terjadi produksi oksida nitrat berkurang. Nikotin merangsang pelepasan katekolamin, yang meningkatkan agregasi trombosit dan trombosis. Trombosit berkontribusi pada pertumbuhan plak melalui pertambahan trombus. Nikotin juga menginduksi resistensi insulin dan dislipidemia, peradangan pembuluh darah, pertumbuhan pembuluh darah abnormal, dan hilangnya endotel fungsi homeostatik dan regeneratif. Nikotin memiliki tindakan langsung pada elemen seluler yang berpartisipasi dalam plak pembentukan.

Semua efek nikotin ini mengakibatkan terjadinya PAD, serta melalui faktor turunan trombosit dapat menginduksi proliferasi sel otot polos pembuluh darah. Bahkan, nikotin memiliki tindakan langsung pada elemen seluler yang berpartisipasi dalam pembentukan plak untuk meningkatkan perkembangan plak terlepas dari nilai lipid plasma. Selain itu nikotin juga sebagai radikal bebas langsung dari komponen asap rokok atau aktivasi radikal bebas sumber endogen menyebabkan stres oksidatif yang merupakan kontributor utama aterosklerosis dan PAD (Akalu, Birhan, 2020).

Karakteristik riwayat hipertensi, menunjukkan mayoritas responden dengan hipertensi yaitu sebanyak 79 responden $(60 \%)$, mayoritas terdistribusi pada kelompok acupressure sebanyak 26 responden $(78,8 \%)$. Dari hasil pengukuran tekanan darah saat penelitian diperoleh mayoritas hipertensi stage I sebanyak 59 responden (44\%). Terbukti pada penelitian Akalu, Birhan (2020) terhadap 280 pasien DM tipe 2 di Ethiopia, menunjukkan bahwa mayoritas responden dengan hipertensi sebanyak 146 orang $(52,1 \%)$ terjadi pada pasien DM tipe 2 dengan PAD. Adanya hipertensi akan memperberat disfungsi endotel dan meningkatkan risiko penyakit kardiovaskuler.

Hipertensi dapat menyebabkan penebalan pembuluh darah arteri menyebabkan diameter pembuluh darah menyempit. Penyempitan pembuluh darah akan memengaruhi pengangkutan metabolisme dalam darah, sehingga kadar glukosa dalam darah akan terganggu. Insiden diabetes melitus $2 / 3$ lebih tinggi pada pasien dengan hipertensi sehingga hipertensi juga memengaruhi komplikasi PAD (Ainsyah, Lusno, 2018).

Karakteristik lama menderita DM, menunjukkan mayoritas responden menderita DM lebih dari 10 tahun dan terdistribusi pada kelompok acupressure sebanyak 20 responden (60,6\%). Terbukti pada penelitian dilakukan oleh Chen et al., (2018) terhadap 1096 pasien DM tipe 2 di China, menunjukkan bahwa mayoritas responden menderita DM lebih dari 10 tahun sebanyak 887(80,9\%). PAD umumnya terjadi setelah 5 tahun terkena diabetes melitus tipe 2. Rendahnya kontrol glikemik dan dislipidemia akan meningkatkan terjadinya neuropati diabetik. Semakin lama mengalami diabetes melitus tipe 2 maka semakin tinggi pula kejadian komplikasi yang dialami. Durasi diabetes melitus tipe 2 dengan tingkat kadar gula darah yang tinggi akan mempengaruhi perubahan dinding pembuluh darah (Ainsyah, Lusno, 2018). Tingginya kadar gula darah yang kronis menyebabkan penurunan sekresi insulin. 
Glukosa tersebut akan berubah menjadi sorbitol yang menyebabkan kerusakan sel saraf. Semakin lama seseorang menderita DM maka proses ini akan berlangsung lebih lama dan memperparah terjadinya kerusakan sel saraf (Ainsyah, Lusno, 2018).

\section{Acupresure dan Senam Kaki terhadap PAD}

Acupressure secara teori dapat mencegah terjadinya PAD dengan meningkatkan sirkulasi aliran darah. Acupressure dapat mengembalikan keseimbangan yang ada didalam tubuh, dengan memberikan rangsangan aliran energi untuk menyeimbangkan Yin dan Yang. Analisis penelitian ini sesuai dengan pernyataan yang disampaikan oleh Chen et al., (2018) menyatakan bahwa PAD dapat dicegah dengan terapi komplementer, salah satunya dengan acupressure.

Acupressure sebagai salah satu intervensi pada penelitian ini terbukti dapat memperbaiki sirkulasi aliran darah dengan menurunkan resiko terjadi PAD. Terbukti secara signifikan pada penelitian Feng et al., (2018) terhadap pasien DM tipe 2 dengan PAD di China, hasil penelitian menunjukkan bahwa ada pengaruh yang signifikan pada kelompok acupressure terhadap PAD dengan $p$ value $=0,01(<0,05)$. Penelitian lain oleh Chen et al., (2018) terhadap 887 dari 1096 pasien DM tipe 2 dengan PAD di China, hasil penelitian menunjukkan bahwa ada pengaruh yang signifikan pada kelompok acupressure terhadap PAD pada pasien DM tipe 2 dengan $p$ value $=0,01$. Hiperglikemia terjadi dikarenakan disfungsi sekresi insulin atau gangguan fungsi biologis insulin sebagai faktor penyebab utama dari DM. Terapi acupressure memiliki efek nyata pada penurunan glukosa darah. Efek acupressure di Zusanli (ST36) dan Sanyinjiao (SP6) pada pasien DM tipe 2 menunjukkan adanya peningkatan IRS-1, PI3K, Akt2, dan eNOS di endotel pembuluh darah. Ini jalur transduksi sinyal pada insulin didalam sel endotel vaskular. Ketika sensitivitas insulin ditingkatkan, jalur pensinyalan dapat lebih diaktifkan dan memproduksi NO. Dengan cara ini, vaskular disfungsi endotel berkurang dan terjadi vasodilatasi. NO adalah penghambat neurotransmitter dan kekurangan NO dapat menyebabkan gangguan fungsi saraf. Peningkatan molekul-molekul ini tampaknya memberikan efek pada pasien PAD (Feng et al., 2018).

Senam kaki dipilih sebagai salah satu intervensi dalam penelitian ini karena berdasarkan kajian ilmiah, pasien DM tipe 2 beresiko empat kali terjadinya PAD. Menurut (American Diabetes Association, 2018), menyatakan bahwa PAD pada pasien DM tipe 2 merupakan salah satu komplikasi makrovaskular di pembuluh darah tungkai bawah. Hasil study oleh Kanokphichayakrai et al., (2018) di Hospital Phitsanulok Thailand, menyatakan bahwa dari 187 pasien DM tipe 2 dengan komplikasi PAD sebesar $16,6 \%$ (31/187 pasien) dengan grade $\mathrm{I} A B I \leq 0,90$.

Hiperglikemi pada pasien DM dapat mengakibatkan disfungsi endotel di pembuluh darah arteri. Lapisan sel endotel dari arteri merupakan organ yang aktif secara biologi, oleh karena kemampuannya dalam memproduksi zat vasodilator yang dinamakan endothelium derived relaxing factors (EDRF) yang dikenal juga sebagai Nitric Oxide (NO). NO adalah stimulus yang penting dari vasodilatasi dan mengurangi terjadinya peradangan melalui modulasi interaksi leukosit dan dinding pembuluh darah dan lebih jauh NO membatasi migrasi dan proliferasi vascular smooth muscle cell (VSMC) serta membatasi aktivasi dari sel pembeku darah. Disfungsi endotel pada pasien DM berhubungan dengan resistensi insulin, menunjukkan peranannya sebagai penyebab awal perkembangan terjadinya aterosklerosis (early atherosclerotic cardiovascular disease) (Muhammad, 2018). 
Senam kaki bertujuan untuk meningkatan sirkulasi darah di kaki untuk mencegah terjadinya PAD. Menurut Suyanto (2017) menyatakan bahwa latihan ringan termasuk senam kaki dapat meningkatkan pelebaran mikrovaskular, mengurangi stres oksidatif. Penelitian yang relevan juga menyatakan bahwa senam kaki dapat menyebabkan pemulihan fungsi syaraf perifer dengan menghambat reduktase aldosa yang mengarah ke menurunnya NADPH yang akan meningkatkan aktifitas sel endotel. Aktivitas fisik dapat menurunkan kadar gula darah puasa dan mencegah komplikasi. Otot dalam tubuh akan bereaksi dengan glukosa yang tersimpan dalam tubuh sehingga akan mengurangi penyimpanan glukosa dalam tubuh. Glukosa di dalam darah akan menurun sehingga gula darah dalam tubuh dapat dikontrol (Ainsyah, Lusno, 2018). Senam kaki sebagai salah satu latihan fisik merupakan strategi tindakan intervensi yang efektif untuk mencegah PAD.

\section{Intervensi yang Memberikan Pengaruh Paling Besar terhadap PAD}

Uji regresi logistik ordinal dilakukan untuk mengetahui pengaruh setiap intervensi. Adanya pengaruh diketahui dari nilai $\mathrm{p}$, jika nilai $\mathrm{p}<0,05$ maka dikatakan berpengaruh, dan jika $\mathrm{p}>0,05$ dikatakan tidak berpengaruh. Pada penelitian ini, semua intervensi mempunyai nilai $\mathrm{p}<0,05$ sehingga dikatakan semua intervensi berpengaruh terhadap PAD klien DM tipe 2. Berdasarkan nilai p pada hasil parameter estimate yang sudah dilakukan, diketahui bahwa nilai p yang paling rendah diantara ketiga kelompok intervensi adalah pada kelompok intervensi gabungan acupressure dengan senam kaki sehingga secara statistik dapat disimpulkan bahwa gabungan acupressure dengan senam kaki mempunyai kemaknaan paling tinggi terhadap PAD dibandingkan intervensi yang lain.

Besarnya pengaruh setiap intervensi dilihat dari besarnya nilai estimate pada hasil parameter estimate dengan asumsi bahwa nilai estimate yang paling berpengaruh diantara ketiga intervensi tersebut menunjukkan pengaruh yang paling tinggi. Berdasarkan nilai estimate pada tiga kelompok intervensi, diketahui bahwa intervensi gabungan acupressure dengan senam kaki mempunyai nilai paling tinggi dibandingkan intervensi yang lain, yaitu sebesar 1,174. Hasil estimate tersebut menyimpulkan bahwa secara statistik gabungan acupressure dengan senam kaki memberikan pengaruh paling besar terhadap PAD klien DM tipe 2.

Intervensi ini dikatakan berpengaruh menurunkan resiko PAD pada klien DM tipe 2, yang terjadi karena adanya resistensi insulin dan peningkatan kadar gula darah bisa merusak pembuluh darah, saraf dan struktur internal lainnya sehingga klien DM tipe 2 mengalami penebalan dalam dinding pembuluh darah yang disebabkan dengan arterosklerosis yang berdampak terhadap gangguan sirkulasi aliran darah (Muhammad, 2018).

Menurut Chen et al., (2018) menyatakan bahwa PAD dapat dicegah dengan terapi komplementer, salah satunya acupressure. Acupressure direkomendasikan pada pasien DM tipe 2 dengan PAD sebab intervensi ini dapat merangsang gelombang saraf sehingga mampu membantu melancarkan aliran darah. Terbukti pada penelitian Qi Z Pang (2018) terhadap 126 pasien DM dengan PAD di China. Hasil penelitian menunjukkan bahwa ada peningkatan aliran darah dikaki setelah dilakukan acupressure secara signifikan terhadap PAD dengan $\mathrm{p}$ value 0,001 .

Berdasarkan efektifitas intervensi gabungan acupressure dengan senam kaki, peneliti menggabungkan kedua intervensi tersebut kedalam penelitian ini. Pengaruh gabungan acupressure dengan senam kaki terhadap PAD terbukti mempengaruhi PAD 
secara bermakna. Pengaruh tersebut dibuktikan dengan hasil uji beda before-after yang menunjukkan ada perbedaan PAD sebelum dan sesudah intervensi dengan nilai $\mathrm{p}=0,000$; hasil uji beda independen yang menunjukkan ada perbedaan PAD antara kelompok intervensi gabungan acupressure dengan senam kaki dengan kelompok kontrol dengan nilai $\mathrm{p}=0,000$; dan hasil uji regresi logistik ordinal kelompok intervensi gabungan acupressure dengan senam kaki menunjukkan nilai estimate paling tinggi dibandingkan dengan intervensi lainnya, yaitu 1,174 dengan $\mathrm{p}=0,000$.

Senam kaki dan acupressure dapat meningkatkan nitrat oksida, penghambatan produksi berlebihan protein kinase $\mathrm{C}$ dan perbaikan metabolisme glutation. Glutation merupakan antioksidan sel untuk mencegah kerusakan oksidatif (Qi et al., 2018). Gabungan dari kedua tindakan tersebut diharapkan akan mempercepat pengurangan resiko PAD terutama peningkatan sensasi kaki.

\section{SIMPULAN}

Karakteristik responden berdasarkan jenis kelamin sebagian besar perempuan dalam rentang usia 60-74 tahun, dengan riwayat tidak merokok, memiliki riwayat hipertensi, dan lama menderita DM lebih dari 10 tahun. Hasil pengukuran ABI dengan menggunakan vascullar dopler pada pasien DM tipe 2 setelah diberikan intervensi menunjukan nilai ABI meningkat sehingga terdapat pengaruh acupressure dan senam kaki terhadap tingkat PAD pada pasien DM tipe 2.

Gabungan acupressure dan senam kaki lebih efektif untuk meningkatkan sirkulasi aliran darah dalam mencegah terjadinya PAD. Dengan demikian, acupressure dan senam kaki efektif sangat potensial diterapkan untuk pengembangan kemandirian perawat dalam memberikan edukasi, discharge planning pada pasien DM tipe 2.

\section{SARAN}

\section{Bagi Praktik Keperawatan}

Gabungan acupressure dengan senam kaki secara statistik terbukti paling berpengaruh terhadap PAD pada klien DM tipe 2, sehingga institusi rumah sakit diharapkan dapat memproses "kebijakan" terkait hasil penelitian sebagai tindakan mandiri keperawatan. Kepada perawat juga perlu dilakukan sosialisasi agar perawat mampu untuk melaksanakan intervensi mandiri keperawatan dan mampu mengukur ABI untuk membantu klien DM tipe 2 mendeteksi dini terhadap PAD. Pemeriksaan ABI sebaiknya dimasukkan dalam prosedur pemeriksaan pada klien DM tipe 2 terutama bagi pasien berusia 50 tahun, menderita DM lebih dari 10 tahun.

\section{Bagi Pendidikan Keperawatan}

Pengembangan kurikulum terapi komplementer terhadap menurunkan resiko PAD pada klien DM tipe 2 dan program praktek cara pengukuran ABI.

\section{Bagi Peneliti Keperawatan}

Pengembangan kajian ilmiah berupa penelitian lanjut untuk mengembangkan dan memperdalam penelitian ini, seperti penelitian yang melibatkan faktor-faktor yang belum dikendalikan dalam penelitian ini, misalnya kadar kolesterol, kadar kreatinin serum dan kadar HbA1c, serta pemberian intervensi dalam rentang waktu lebih dari empat minggu.

\section{Bagi Penderita DM tipe 2}

Kepada penderita DM tipe 2 disarankan untuk melakukan senam kaki minimal tiga kali seminggu secara rutin dan mandiri, melakukan pemeriksaan ABI dengan menggunakan vascular doppler sebagai deteksi dini terjadinya PAD, kepada responden 
yang merokok untuk stop merokok, dan kepada responden yang hipertensi untuk teratur minum obat antihipertensi serta menjaga tekanan darah tidak boleh lebih dari $130 / 90 \mathrm{mmHg}$.

\section{DAFTAR PUSTAKA}

ADA. (2020). Classification and Diagnosis of Diabetes: Standards of Medical Care in Diabetes-2020. In Diabetes care (Vol. 43, pp. S14-S31). https://doi.org/10.2337/dc20-S002

ADA (American Diabetes Association). (2018). Standards of Medical Care in Diabetes. Turkish Journal of Endocrinology and Metabolism, 14, 11-16. https://doi.org/doi.org/10.2337/diacare.27.2007.s15

Ainsyah, R. W., \& Lusno, M. F. (2018). Faktor Protektif Kejadian Diare pada Balita di $\begin{array}{llll}\text { Surabaya. Jurnal Berkala } & \text { Epidemiologi, }\end{array}$ https://doi.org/10.20473/jbe.v6i12018.51-59

Akalu, Y., \& Birhan, A. (2020). Peripheral Arterial Disease and Its Associated Factors among Type 2 Diabetes Mellitus Patients at Debre Tabor General Hospital, Northwest Ethiopia. Journal of Diabetes Research, 2020. https://doi.org/10.1155/2020/9419413

American Diabetes Association. (2018). Standard Medical Dare in diabetes 2018. The Journal of Clinical and Applied Research and Education. https://doi.org/10.2337/dc18-Sint01

Chen, Q. F., Cao, D., Ye, T. T., Deng, H. H., \& Zhu, H. (2018). Peripheral Arterial Disease in Type 2 Diabetes Is Associated with an Increase in Fibrinogen Levels. International Journal of Endocrinology, 2018. https://doi.org/10.1155/2018/3709534

Feng, Y., Fang, Y., Wang, Y., \& Hao, Y. (2018). Acupoint Therapy on Diabetes Mellitus and Its Common Chronic Complications: A Review of Its Mechanisms. In BioMed Research International (Vol. 2018). https://doi.org/10.1155/2018/3128378

IDF. (2019). IDF Diabetes Atlas, 9th edn. Brussels, Belgium. In Atlas de la Diabetes de la FID

Indriani, S., Amalia, I. N., \& Hamidah, H. (2019). Hubungan antara Self Care dengan Insidensi Neuropaty Perifer pada Pasien Diabetes Mellitus Tipe II RSUD Cibabat Cimahi 2018. Jurnal Ilmu Kesehatan Bhakti Husada: Health Sciences Journal, 10(1), 54-67. https://doi.org/10.34305/jikbh.v10i1.85

Kanokphichayakrai, K., Kaewmahanin, W., Tangvarasittichai, O., \& Tangvarasittichai, S. (2018). Ankle Brachial Index (ABI) Measurement Associated with High Sensitivity-C-Reactive Protein, Insulin Resistance and Pulse Pressure Levels in Type 2 Diabetes Mellitus Patients. Madridge Journal of Diabetes, 2(1), 31-35. https://doi.org/10.18689/mjd-1000106

Kemeneterian RI. (2018). Laporan Provinsi Kepulauan Riau Riskesdas 2018. Lembaga Penerbit Badan Penelitian dan Pengembangan Kesehatan 2019. www.kemkes.go.id

Muhammad, I. A. (2018). Diabetic Foot Ulcer: Synopsis of the Epidemiology and Pathophysiology. International Journal of Diabetes and Endocrinology, 3(2), 23. https://doi.org/10.11648/j.ijde.20180302.11

Perkeni. (2019). Pedoman Pemantauan Glukosa Darah Mandiri (p. 28) 
Qi, Z., Pang, Y., Lin, L., Zhang, B., Shao, J., Liu, X., \& Zhang, X. (2018). Acupuncture Combined with Hydrotherapy in Diabetes Patients with Mild Lower-Extremity Arterial Disease: A Prospective, Randomized, Nonblinded Clinical Study. Medical Science Monitor, 24, 2887-2900. https://doi.org/10.12659/MSM.909733

Riskesdas. (2018). Hasil Utama Riset Kesehatan Dasar. Kementrian Kesehatan Republik Indonesia, 1-100. https://doi.org/

Suyanto, S. (2017). Pengaruh Terapi SPA dan Senam Kaki Diabetik pada Pasien Neuropati Perifer Diabetik. Jurnal Keperawatan dan Pemikiran, 3(4), 29-37. http://jurnal.unissula.ac.id/index.php/jnm/article/download/2276/1715 